\title{
Concentrations of immunoreactive inhibin in ovarian and peripheral venous plasma and follicular fluid of Booroola ewes that are homozygous carriers or non-carriers of the Fec $^{\mathrm{B}}$ gene
}

\author{
K. P. McNatty, D. A. Heath, N. L. Hudson, K. Ball and L. Condell \\ MAF Technology, Wallaceville Animal Research Centre, Ministry of Agriculture and Fisheries, \\ PO Box 40063, Upper Hutt, New Zealand
}

\begin{abstract}
Summary. No gene-specific differences were found during either the luteal or follicular phases of the oestrous cycle in the venous secretion rates of ovaries or in concentrations of immunoreactive inhibin in peripheral plasma between Booroola ewes that were homozygous carriers (BB) or non-carriers $(++)$ of the $\mathrm{Fec}^{\mathbf{B}}$ gene. In three experiments in which concentrations of plasma inhibin and follicle-stimulating hormone (FSH) were compared, gene-specific differences were noted for FSH $(P<0.05)$, but no significant correlations were noted between FSH and inhibin for either genotype. Granulosa cells and follicular fluid, but not theca interna, stroma or corpora lutea, were the major intra-ovarian sites of inhibin; no gene-specific differences were noted for inhibin concentrations in follicular fluid or in any of the intra-ovarian tissues. The mean concentrations of inhibin in follicular fluid remained constant irrespective of follicular diameter whereas the mean total contents of inhibin increased significantly with increasing diameter $(P<0.05)$. Inhibin secretion rates were four times higher in ovaries with oestrogen-enriched follicles (i.e. $\geq 50 \mathrm{ng}$ oestradiol ml-1) than in ovaries with no such follicles $(P<0.01)$. Moreover, inhibin concentrations were higher in follicular fluid of oestrogen-enriched follicles than in those with low oestrogen (i.e. $\left.<50 \mathrm{ng} \mathrm{ml}^{-1} ; P<0.05\right)$. Ovariectomy resulted in a significant reduction in concentrations of immunoreactive inhibin from plasma $(P<0.01)$. The residual plasma inhibin in some Booroola ewes was not associated with genotype.

It is concluded that, although antral follicles are a major source of inhibin in Booroola ewes, immunoreactive inhibin is not associated with the $\mathrm{Fec}^{\mathrm{B}}$ gene and is not responsible for the gene-specific differences in concentrations of FSH in plasma.
\end{abstract}

Keywords: Booroola ewes; $\mathrm{Fec}^{\mathrm{B}}$ gene; inhibin; FSH; peripheral plasma; ovarian secretion rates

\section{Introduction}

Booroola ewes possess a major gene, $\mathrm{Fec}^{\mathbf{B}}$, that influences their ovulation rate (i.e. the number of ovulations per oestrous cycle; for review see Bindon, 1984). Previously, this gene was referred to by the symbol F (Davis et al., 1982; Piper et al., 1985), but it has been revised to $\mathrm{Fec}^{\mathrm{B}}$ (i.e. $\mathrm{Fec}=$ fecundity; $\mathrm{B}=$ Booroola) to distinguish it from other postulated genes for prolificacy that may or may not be identical to or allelic with $\mathrm{Fec}^{\mathrm{B}}$ (Piper \& Bindon, 1991). Homozygotes (BB), heterozygotes $(\mathrm{B}+)$ and non-carriers $(++)$ of the $\mathrm{Fec}^{\mathrm{B}}$ gene are segregated on the basis of ovulation rate recordings of $\geq 5,3$ or 4 , and 1 or 2, respectively (Davis et al., 1982).

Studies have shown that follicle-stimulating hormone (FSH) and, to a lesser extent, luteinizing hormone (LH) are consistently higher in BB than in ++ ewes that were either ovary-intact, ovariectomized ewes or ovariectomized ewes with hypothalamic-pituitary disconnection treated with 
gonadotrophin-releasing hormone (GnRH) (McNatty et al., 1987, 1989a, 1991a). Collectively, these results suggest that some association exists between the $\mathrm{Fec}^{\mathbf{B}}$ gene and the pituitary, although the precise mechanism is unknown. Montgomery et al. (1990) reported that polymorphisms of the $F S H \beta$ gene are not linked to the $\mathrm{Fec}^{\mathbf{B}}$ gene. Moreover, no gene-specific differences have been noted in GnRH-receptor-binding characteristics, FSH isoforms or plasma clearance rates or steroid or inhibin feedback effects (Robertson et al., 1984; Fry et al., 1987; McNatty et al., 1989b; Fleming et al., 1990a). In addition to the differences in pituitary expression among the Booroola genotypes, there is also evidence that ovaries from BB and B+ ewes have a lower bioactive inhibin content than those of control Merinos not of the Booroola strain (Cummins et al., 1983) and that the immunoreactive inhibin concentrations in peripheral plasma of BB and B + ewes are lower than those of control Merinos (unpublished observations of B. M. Bindon, J. K. Findlay \& M. A. Hillard, cited in McNatty et al., 1991b). These data suggest that the $\mathrm{Fec}^{\mathrm{B}}$ carrier may have a deficiency in secreting inhibin thereby accounting, at least in part, for the higher plasma FSH concentrations observed in ovary-intact $\mathrm{BB}$ and $\mathrm{B}+$ ewes relative to ++ ewes. In contrast to the above studies with BB/B + ewes and non-Booroola Merino controls, Henderson et al. (1991) reported that the highest mean amounts of bio- or immunoreactive inhibin produced by granulosa cells from BB ewes in vitro was similar to that produced by ++ ewes. Although granulosa cells are considered to be the major cellular source of inhibin in sheep, these data from in vitro experiments could not demonstrate a deficiency in BB relative to ++ ewes with respect to inhibin synthesis. It could be argued that the failure to demonstrate a deficiency in granulosa cells from $\mathrm{Fec}^{\mathbf{B}}$ sheep was due to inappropriate culture conditions. However, the evidence from in vivo studies for an inhibin deficiency in $\mathrm{Fec}^{\mathbf{B}}$ sheep critically depends on the acceptance that non-Booroola Merinos are equivalent to ++ control animals, and this is uncertain.

To determine whether there is an association between inhibin and the $\mathrm{Fec}^{\mathrm{B}}$ gene, we examined the ovarian secretion rates and peripheral plasma concentrations of inhibin together with the follicular contents and concentrations of inhibin during the luteal and follicular phases of Booroola ewes that were homozygous carriers or non-carriers of the $\mathrm{Fec}^{\mathrm{B}}$ gene. The plasma FSH concentrations were also compared in the same genotypes.

\section{Materials and Methods}

\section{Animals}

Booroola Merino $(n=70)$ and Booroola $\times$ Romney ewes $(n=37)$ were classified as $++(n=52)$ or $\mathrm{BB}(n=55)$ genotypes based on pedigree analysis; all BB animals were derived from matings between progeny-tested BB sires and BB ewes and all ++ animals were progeny of ++ progeny-tested sires mated with ++ ewes. The ovulation rates of $\geq 5$ for the BB and $1-2$ for the ++ genotypes were confirmed by laparoscopy as described by Davis et al. (1982). The mean $( \pm$ SEM) ages of the ++ and BB genotypes were $5.9 \pm 0.2$ and $6 \cdot 2 \pm 0 \cdot 1$ years, respectively. For each experiment, BB and ++ animals were matched as closely as possible for breed, age and bodyweight. The BB and ++ ewes originated from at least 17 different sires; in some instances, individual sires could not be identified for some of the ewes. All experiments were performed in accordance with the 1987 Animals Protection (Codes of Ethical Conduct) Regulations of New Zealand after approval was granted by the Animal Ethics Committee at the Wallaceville Research Centre.

\section{Experiments}

Experiment 1. The ovarian secretion rates of inhibin were measured on day 10 of the oestrous cycle (five BB and five ++ ewes) and at $36 \mathrm{~h}$ after a cloprostenol-induced luteolysis (five BB and five ++ ewes); cloprostenol was given on day 10 of the cycle. For each genotype at day 10 or at $36 \mathrm{~h}$ after cloprostenol treatment, three Booroola Merino and two Booroola Romney ewes were studied. The method of collecting ovarian venous blood under sodium thiopentone anaesthesia was as described by McNatty et al. (1981). After the ovarian and peripheral venous samples were collected, all ewes were ovariectomized and additional peripheral blood samples were collected at $6 \mathrm{~h}, 24 \mathrm{~h}$ and at $\geq 55$ days after ovariectomy. The ovaries from these ewes were collected into minimum essential medium (MEM

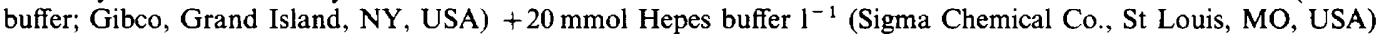
$+0.1 \%(\mathrm{w} / \mathrm{v})$ BSA ( $>97 \%$ pure; Immuno-chemical Products Ltd, Auckland, NZ). All follicles ( $\geq 1 \mathrm{~mm}$ diameter) 
and corpora lutea were dissected free of extraneous tissue. Granulosa cells, theca interna and follicular fluid were isolated from individual follicles which were characterized as non-atretic or atretic. Briefly, a non-atretic follicle was defined as one that contained a vascularized theca interna, no debris in follicular fluid, $\geq 25 \%$ of the maximum number of granulosa cells for its size and genotype and an oocyte of healthy appearance (McNatty et al., 1986). The follicular fluid volumes from individual follicles were recorded and thereafter the fluids were stored at $-20^{\circ} \mathrm{C}$ in $100 \mu \mathrm{l}$ of assay buffer $\left(0 \cdot 1 \mathrm{~mol}\right.$ phosphate buffer $1^{-1}$ with $0 \cdot 15 \mathrm{~mol} \mathrm{NaCl} 1^{-1}$ and $\left.5 \%(\mathrm{w} / \mathrm{v}) \mathrm{BSA}, \mathrm{pH} 7 \cdot 4\right)$. The pooled theca interna, stroma from each ovary and individual corpora lutea were homogenized in assay buffer and stored at $-20^{\circ} \mathrm{C}$, whereas the granulosa cells from individual follicles were washed in MEM buffer and stored at $-20^{\circ} \mathrm{C}$. Supernatants from the homogenized tissues and sonicated granulosa cells were assayed for inhibin.

Experiment 2. The peripheral plasma concentrations of inhibin and FSH were examined around a cloprostenol (PG; Coopers-Pitman Moore, Upper Hutt, NZ) induced luteolysis and also around the preovulatory LH surge. For this experiment, nine BB and eight ++ Booroola Merino ewes were each fitted with a jugular venous cannula on day 9 of the oestrous cycle (day $0=$ oestrus), and underwent laparoscopy to determine the ovulation rate. From day 10 of the cycle all animals were bled via the cannula ( $3 \mathrm{ml}$ per collection) at intervals of one hour for $66 \mathrm{~h}$. After $6 \mathrm{~h}$, all animals were given cloprostenol ( $125 \mu \mathrm{g}$, s.c.). Throughout the experiment, the animals were housed together indoors and had unrestricted access to meadow hay, lucerne pellets and water. The animals underwent laparoscopy again one week after blood sampling had finished.

Experiment 3. The daily concentrations of inhibin, FSH and progesterone in plasma throughout a PG-synchronized oestrous cycle were examined. For this experiment, ten BB and ten ++ animals (six Booroola Merino and four Booroola Romneys per genotype) were bled ( $3 \mathrm{ml}$ per collection) via a jugular venous cannula each day beginning the day after the onset of oestrus and continuing for 29 days. They also underwent laparoscopy on day 9 and again on day 29 after oestrus. These animals were housed together indoors with unrestricted access to food and water as in Expt 1 .

Experiment 4. The concentrations of inhibin and FSH in plasma were measured during the luteal phase in another population of ewes on pasture. For this experiment, $26 \mathrm{BB}$ (13 Booroola Merino and 13 Booroola Romney) and $24++(14$ Booroola Merino and 10 Booroola Romney) animals were all bled within $30 \mathrm{~min}$ by jugular venepuncture on three occasions (i.e. Friday, Monday, Wednesday) between day 4 and day 13 of the oestrous cycle. Although the day of cycle for each animal was known, all were at different phases with respect to one another when blood sampling occurred.

\section{Blood samples}

All blood samples were centrifuged at $4000 \mathrm{~g}$ at room temperature for $20 \mathrm{~min}$ within $30 \mathrm{~min}$ of collection and the plasma samples were stored at $-20^{\circ} \mathrm{C}$ until assayed.

\section{Hormone assays}

\section{Follicle-stimulating hormone}

The radioimmunoassay kit used was supplied by The National Institute of Arthritis, Metabolism and Digestive Diseases (NIAMDD), Bethesda, Maryland, USA. The ovine (o) FSH for iodination was NIAMDD-oFSH-I-1, the oFSH reference preparation was NIAMDD-oFSH-RP-1 (biopotency $75 \times \mathrm{NIH}-\mathrm{FSH}-\mathrm{SI}$ ) and the oFSH antiserum was NIAMDD-anti-oFSH-1 (AFP-C5288113). Plasma volume used was $0 \cdot 1 \mathrm{ml}$ and each sample was assayed in duplicate. The internal standards and standard curve samples were prepared in FSH-free hypophysectomized ewe plasma and the minimum detectable concentration was $0 \cdot 2 \mathrm{ng} \mathrm{ml}^{-1}$. The intra- and interassay coefficients of variation for the internal standards were 6.5 and $10.2 \%$, respectively.

\section{Luteinizing hormone}

The radioimmunoassay was identical to that described by McNatty et al. (1989b). Briefly the iodination standard was NIDDK-oLH-I-3 (AFP-9598B), the LH antiserum was raised at Wallaceville and is described by McNatty et al. (1987). The oLH reference preparation was NIAMDD-oLH-S23 (biopotency $2.3 \times \mathrm{NIH}-\mathrm{LH}-\mathrm{S1}$ ). The volume of plasma which was assayed in duplicate was $0.1 \mathrm{ml}$. The internal standards and standard curve samples were prepared in LH-free plasma from hypophysectomized ewes. The overall intra- and interassay coefficients of variation for the internal standards which were included with every standard curve estimation were 6.5 and $9.8 \%$, respectively. The minimal detectable concentration of $\mathrm{LH}$ was $0 \cdot 2 \mathrm{ng} \mathrm{ml}^{-1}$.

\section{Inhibin}

The radioimmunoassay kit was purchased from D. M. Robertson (Monash University, Melbourne, Australia) and consisted of a highly purified $31 \mathrm{kDa}$ bovine inhibin for iodination and a rabbit antibovine $31 \mathrm{kDa}$ inhibin preparation (No. 1989). This assay using antiserum No. 1989 has previously been validated for the measurement of inhibin in peripheral plasma of sheep (Findlay et al., 1990). The antiserum has less than $1 \%$ crossreactivity with ovine FSH, LH, growth hormone, prolactin, bovine activin-A, porcine transforming growth factor- $\beta$, Mullerian inhibiting substance, the reduced and alkylated $\alpha$ - and $\beta$-subunits of bovine inhibin and FSH-suppressing protein (FSP). 
However, there was a $288 \%$ crossreaction with bovine pro- $\alpha$ C-subunit (Robertson et al., 1989). The reference standard was a pool of charcoal-treated ovine follicular fluid (OFF2). The assay buffer was the $0 \cdot 1$ mol phosphate buffer $1^{-1}$ described above. A protocol using delayed addition of tracer and double antibody precipitation was as described previously for the assays of human, bovine (McLachlan et al., 1986) and rat inhibin (Robertson et al., 1988). Standards or unknowns were diluted in either assay buffer or ovariectomized ovine plasma (OOP; previously shown to be free of immunoreactive inhibin-like activity) to a volume of $100 \mu \mathrm{l}$. All homogenized tissue samples were assayed using assay buffer, whereas all plasma samples were assayed using OOP. The efficiency of recovery of inhibin from homogenized ovarian tissues was not determined. A further $100 \mu$ of assay buffer was then added together with $100 \mu \mathrm{l}$ of inhibin antiserum (initial dilution 1 in 3000) and the tubes incubated for $24 \mathrm{~h}$ at room temperature. lodinated $31 \mathrm{kDa}$ inhibin tracer $(10000$ c.p.m. in $100 \mu \mathrm{l}$ assay buffer with $0 \cdot 1 \%$ Triton $\mathrm{X}-100)$ was then added and the tubes incubated for a further $24 \mathrm{~h}$ at room temperature. Goat anti-rabbit IgG (ALGP-050; $100 \mu \mathrm{l}$ of 1:800 in assay buffer; Immuno-chemical Products, Auckland, $\mathrm{NZ}$ ) and $1 \mathrm{ml}$ of $3 \%(\mathrm{v} / \mathrm{v})$ polyethylene glycol in $0.9 \% \mathrm{NaCl}$ were added, and the tubes incubated for a further $18 \mathrm{~h}$ at $4^{\circ} \mathrm{C}$ after which the tubes were centrifuged at $2500 \mathrm{~g}$ for $30 \mathrm{~min}$ at $4^{\circ} \mathrm{C}$, decanted and the radioactivity of the pellet determined.

The sensitivity of the assay (i.e. at $10 \%$ displacement of the tracer) was $<0.5 \mathrm{iu}$ per tube both in the presence and absence of OOP. The mean intra- and interassay coefficients of variation were both $<16 \%$.

The ovarian secretion rates of inhibin were calculated from a knowledge of haematocrit, blood flow and hormone concentration in the ovarian and jugular veins.

\section{Oestradiol and progesterone}

The radioimmunoassay procedures for oestradiol and for progesterone are described by McNatty (1989b). Oestradiol in follicular fluid was assayed directly in diluted aliquots, whereas oestradiol in plasma was subjected to the procedure described by Webb et al. (1985) and McNatty et al. (1989b). The limit of detection for oestradiol was $\leqslant 3 \mathrm{pg}$ per tube and the intra- and interassay coefficients of variation over the range of $3-30 \mathrm{pg}$ were $12 \%$ and $20 \%$, respectively. The secretion rates of oestradiol were calculated as described for inhibin.

Progesterone was extracted from plasma with $2 \times 5$ volumes of petroleum ether (b.p. $40-60^{\circ}$ ). The limit of detection for progesterone was $\leqslant 20 \mathrm{pg}$ per tube and the intra- and interassay coefficients of variation over the range 200 to $1000 \mathrm{pg}$ were $8 \%$ and $10 \%$, respectively. The secretion rates of progesterone were calculated as described for inhibin.

\section{Statistical analysis}

Homogeneity of variance was checked using the Bartlett test. When variances were unequal, values were log transformed and expressed as geometric means (and 95\% confidence limits), otherwise data were presented as arithmetic means \pm SEM.

Mean FSH, inhibin and steroid concentrations and body weights when compared across genotype were analysed by Student's $t$ test. Analysis of intercepts and slopes of regression lines for FSH concentrations after luteolysis or the effect of time after PG injection of oestradiol secretion was by the Kruskal-Wallis test. The sample correlations from successive blood sampling for inhibin or FSH with respect to genotype were tested by Spearman Rank Correlation. For each genotype, the effects of sire were tested by analysis of variance (ANOVA) or Kruskal-Wallis test on ranked hormone values; no sire effects were noted for either FSH or inhibin in any of the experiments. When testing effects of treatment and genotype two-way ANOvAs were performed.

\section{Results}

The inhibin assay: reference standards and parallelism tests for ovine plasma and tissue homogenates

The reference standard OFF2 was calibrated against the WHO porcine standard 86/690 (National Institute of Biological Standards and Control, Potters Bar, Hertfordshire, UK). No significant differences in either the slope or the intercept were noted between the log-logit dose response lines of WHO 86/690 in the presence or absence of OOP; these data were combined (Fig. 1). Relative to the WHO 86/690 standard, OFF2 contained $362 \mathrm{~K} \mathrm{iu} \mathrm{m}^{-1}$ and $534 \mathrm{~K} \mathrm{iu} \mathrm{ml}^{-1}$ in the absence and presence of OOP, respectively. This difference in activity did not occur when purified $31 \mathrm{kDa}$ bovine inhibin standard or $31 \mathrm{kDa}$ recombinant human inhibin A (data not shown) was present in buffer or OOP. The difference in activity of the OFF2 standard in buffer or OOP suggests that there is an interaction between OOP and OFF2 to produce an immunoreactive material recognized by the antisera No. 1989 (see Materials and Methods for inhibin crossreactivity, e.g. Pro- $\alpha$ C). The above values were used to determine the inhibin activity of the unknowns. The inhibin values in serially diluted ovarian venous plasma, peripheral plasma and supernatants of sonicated granulosa cell and homogenates of stromal tissue, corpora lutea or thecal tissues were all parallel to OFF2 and to the WHO reference standard (Fig. 1). 
Granulosa cells, stroma and corpora lutea ( $\mu$ l per tube)
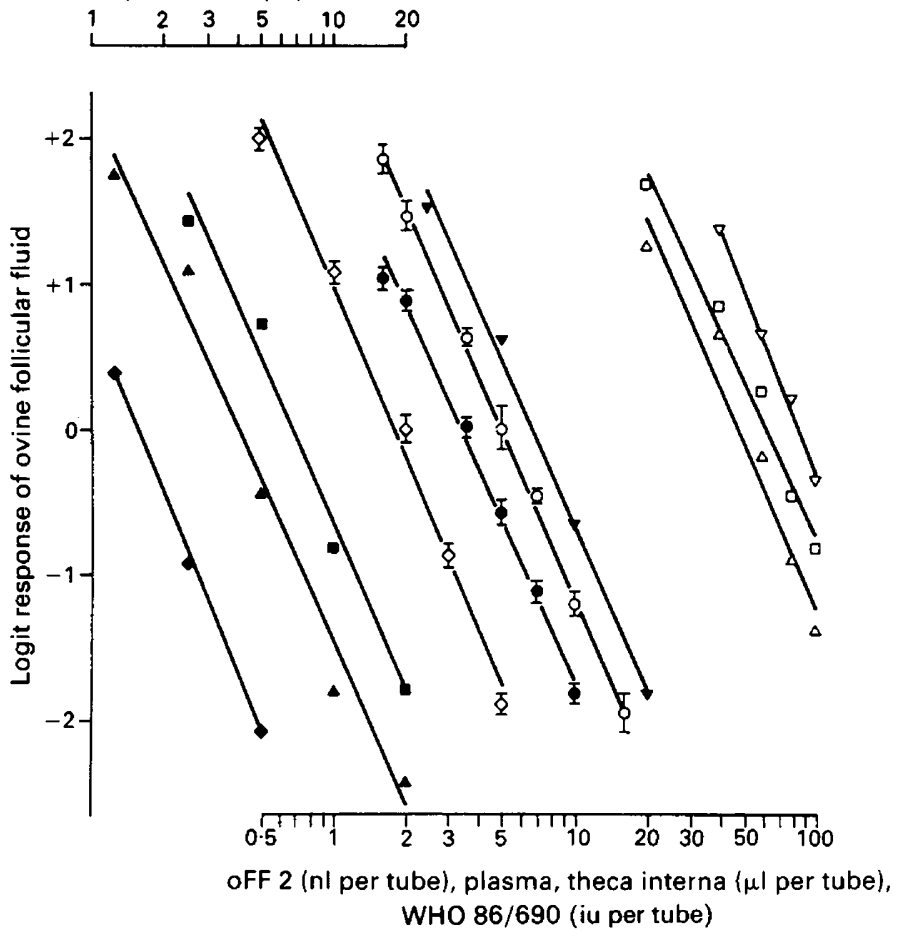

Fig. 1. Logit-log dose-response curves of the ovine follicular fluid standard (oFF2) ( $2 \mathrm{nl}$ per tube) in assay buffer ( $\bigcirc-\bigcirc, n=4)$, or ovariectomized plasma $(-\infty, n=7)$; the WHO inhibin standard $(86 / 690)$ in buffer or ovariectomized plasma $(\diamond-\diamond, n=11)$, ovarian venous plasma $(\triangle \longrightarrow \triangle, n=1)$, ovine ovariectomized plasma $(\square-\square, n=1)$, peripheral venous plasma $(\nabla-\nabla, n=1)$; homogenized theca interna $(\nabla-\nabla, n=1)$, corpora lutea $(\boldsymbol{\square}-\mathbf{\square}, n=1)$, stroma $(\boldsymbol{\Delta}-\longrightarrow, n=1)$ and sonicated granulosa cells $(\bullet-\bullet, n=1)$. Vertical bars refer to SEM from separate experiments.

Ovarian secretion rates of inhibin, oestradiol and progesterone and concentrations of inhibin in peripheral plasma around luteolysis in various Booroola genotypes

The inhibin concentrations in ovarian venous plasma were $4.3 \pm 0.8$ (mean \pm SEM) times higher than in peripheral plasma (Table 1). Two-way ANOVA of peripheral plasma concentrations (treatment, genotype) or ovarian-venous secretion rates (treatment, genotype) revealed no significant treatment or genotype effects or interactions. When inhibin secretion rates from oestrogen-active ( $n=30$ ovaries) and oestrogen-inactive ovaries $(n=10)$ were compared the geometric means (and $95 \%$ confidence limits) were $32 \cdot 2(22 \cdot 6,45 \cdot 7)$ and $8 \cdot 4(3 \cdot 4,19 \cdot 1)$ iu $\mathrm{min}^{-1}$, respectively; oestrogenactive ovaries secreted significantly more inhibin than oestrogen-inactive ovaries $(P<0.001$; Student's $t$ test). Oestrogen-active ovaries were defined as those containing at least 1 antral follicle with $\geq 50 \mathrm{ng} \mathrm{ml}^{-1}$ oestradiol in follicular fluid, whereas an oestrogen-inactive ovary was one devoid of antral follicles with oestradiol concentrations $<50 \mathrm{ng} \mathrm{ml}^{-1}$ (McNatty et al., 1986).

No gene-specific differences were noted for oestradiol or progesterone secretion rates at $0 \mathrm{~h}$ or $36 \mathrm{~h}$ after $\mathrm{PG}$ or after the $0 \mathrm{~h}$ and $36 \mathrm{~h}$ data were combined. When results from both genotypes were combined, the geometric mean (and 95\% confidence limits) of secretion rates at $0 \mathrm{~h}$ and $36 \mathrm{~h}$ after PG for left and right ovaries combined were $0.5(0 \cdot 1,1 \cdot 2)$ and $1 \cdot 8(0 \cdot 7,3 \cdot 7) \mathrm{ng} \mathrm{min}^{-1}$, respectively, for oestradiol and $942(677,1310)$ and $31(12,80) \mathrm{ng} \mathrm{min}^{-1}$, respectively, for progesterone; the mean oestradiol secretion rate at $36 \mathrm{~h}$ after $\mathrm{PG}$ was significantly higher than that at $0 \mathrm{~h}(P<0.05$; 
Table 1. Ovarian secretion rates and peripheral plasma concentrations of inhibin in control and cloprostenol-treated Booroola ewes with respect to genotype (Expt 1)

\begin{tabular}{llcc}
\hline $\begin{array}{c}\text { Booroola genotype } \\
(n)\end{array}$ & Treatment & $\begin{array}{c}\text { Plasma concentration } \\
(\text { iu ml }\end{array}$ & $\begin{array}{c}\text { Ovarian venous secretion } \\
\text { rate }(\text { iu min }\end{array}$ \\
\hline$++(5)$ & Control & $12 \cdot 9(10 \cdot 1,16 \cdot 7)$ & $70 \cdot 0(42 \cdot 0,116 \cdot 6)$ \\
$++(5)$ & Cloprostenol & $16 \cdot 2(10 \cdot 8,24 \cdot 5)$ & $81 \cdot 2(42 \cdot 9,153 \cdot 9)$ \\
BB $(5)$ & Control & $13 \cdot 8(8 \cdot 8,21 \cdot 7)$ & $61 \cdot 1(29 \cdot 2,128 \cdot 0)$ \\
BB $(5)$ & Cloprostenol & $9 \cdot 9(8 \cdot 2,11 \cdot 9)$ & $55 \cdot 6(36 \cdot 9,84 \cdot 0)$ \\
\hline
\end{tabular}

${ }^{a}$ Values are geometric means (and $95 \%$ confidence limits).

$n=$ number of sheep. Control animals were sampled on day 10 of the oestrous cycle whereas the cloprostenol-treated animals were sampled $36 \mathrm{~h}$ after cloprostenol injection given on day 10 of the oestrous cycle. Secretion rates were the sum of those from the left and right ovaries.

Student's $t$ test). The mean progesterone secretion rate at $36 \mathrm{~h}$ was significantly lower than that at $0 \mathrm{~h}(P<0.001$; Student's $t$ test $)$, but no significant linear correlation was noted between the secretion rates of oestradiol and inhibin or progesterone and inhibin.

\section{Effect of ovariectomy on plasma inhibin concentrations}

No significant genotype effects were noted for plasma inhibin concentrations at 0,6 and $24 \mathrm{~h}$ or $\geq 55$ days after ovariectomy. When the inhibin values for the $\mathrm{BB}$ and ++ genotypes were pooled ( $n=20$ sheep), the respective mean \pm SEM. concentrations at $0,6,24 \mathrm{~h}$ and $\geq 55$ days were $13.6 \pm 1 \cdot 0,7 \cdot 2 \pm 0 \cdot 7,8 \cdot 2 \pm 1 \cdot 1$ and $7 \cdot 0 \pm 1 \cdot 3 \mathrm{iu} \mathrm{ml}^{-1}$; the values at $0 \mathrm{~h}$ were significantly higher than at each of the other times $(P<0.01)$. At $\geq 55$ days after ovariectomy, inhibin could not be detected in $45 \%$ of the ewes (i.e. $<5 \mathrm{iu} \mathrm{ml}^{-1}$, but in the other ewes values ranged between 5 and $24 \mathrm{iu} \mathrm{ml}^{-1}$ ). For individual animals, the inhibin concentrations were always lower after ovariectomy. Serial dilution of plasma from ovariectomized ewes with immunoreactive inhibin showed that this material ran parallel with plasma inhibin from ovary-intact ewes and with the WHO and OFF2 standards. The example (Fig. 1) shows the highest inhibin concentration found in an ovariectomized ewe.

\section{Effect of follicular diameter, treatment and Booroola genotype on number of corpora lutea and ovarian follicles}

No effect of PG treatment or genotype was noted on the total number of follicles or on follicles in the $1-<2.5$ or $\geq 2.5-<5.0 \mathrm{~mm}$ size range. For the BB and ++ genotypes, the geometric means (and $95 \%$ confidence limits) of total numbers of follicles were $22 \cdot 3(18 \cdot 9,29 \cdot 3)$ and $22 \cdot 9(14 \cdot 7,35 \cdot 2)$, respectively. Moreover, the geometric mean (and $95 \%$ confidence limits) of numbers of follicles in the $1-<2 \cdot 5, \geq 2 \cdot 5-<5.0$ and $\geq 5.0 \mathrm{~mm}$ size range were $16.5(14 \cdot 9,19 \cdot 2), 4 \cdot 2(3 \cdot 1,5 \cdot 4)$ and 0 , respectively, for the BB genotype and $18 \cdot 3(11 \cdot 3,29 \cdot 3), 2 \cdot 2(0 \cdot 9,4 \cdot 4)$ and $1 \cdot 5(0 \cdot 9,2 \cdot 4)$, respectively, for the ++ genotype. For each genotype, the numbers of corpora lutea were also not different between the day 10 control and PG treatment groups. For control and treatment groups combined ( $n=10$ ewes per genotype) the geometric means (and $95 \%$ confidence limits) of numbers of corpora lutea were $5 \cdot 1(4 \cdot 0,6 \cdot 4)$ for the BB genotype and $1 \cdot 7(1 \cdot 3,2 \cdot 1)$ for the ++ genotype, respectively. No genotype or treatment effects were noted in the proportions of non-atretic follicles either overall or for each size range of follicles. Irrespective of treatment or genotype, approximately $35 \%$, $76 \%$ and $90 \%$ of the $1-<2.5 \mathrm{~mm}, \geq 2.5-<5.0 \mathrm{~mm}$ and $\geq 5.0 \mathrm{~mm}$ diameter follicles, respectively, were non-atretic.

\section{Inhibin in ovarian follicular fluid with respect to Booroola genotype, treatment and follicular diameter}

No effect of treatment or genotype was found in inhibin content for each range of follicular diameters (Table 2). The inhibin content increased with increasing follicular diameter with the 
Table 2. Effect of Booroola genotype, treatment with cloprostenol and follicular diameter on inhibin content of ovarian follicles

\begin{tabular}{llccc}
\hline & & \multicolumn{3}{c}{ Inhibin content* } \\
\cline { 3 - 5 } $\begin{array}{l}\text { Booroola } \\
\text { genotype }\end{array}$ & Treatment & $\begin{array}{c}\text { Follicular diameter } \\
1-<2.5 \mathrm{~mm}\end{array}$ & $\begin{array}{c}\text { Follicular diameter } \\
\geq 2 \cdot 5-<5 \cdot 0 \mathrm{~mm}\end{array}$ & $\begin{array}{c}\text { Follicular diameter } \\
\geq 5.0 \mathrm{~mm}\end{array}$ \\
\hline++ & Control & $615^{\mathrm{a}}$ & $7446^{\mathrm{b}}$ & $28362^{\mathrm{c}}$ \\
& & $(396,955)$ & $(2075,26721)$ & $(18607,43230)$ \\
& Cloprostenol & $488^{\mathrm{a}}$ & $4055^{\mathrm{b}}$ & $33213^{\mathrm{c}}$ \\
& & $(232,1024)$ & $(703,23386)$ & $(19956,55238)$ \\
BB & Control & $(213,1305)$ & $(4502,9229)$ & - \\
& Cloprostenol & $405^{\mathrm{a}}$ & $6850^{\mathrm{b}}$ & - \\
& & $(219,748)$ & $(4369,10740)$ & \\
& & &
\end{tabular}

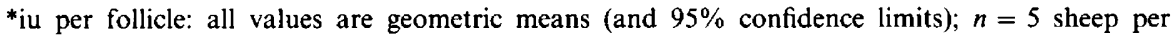
treatment.

a,b,c $P<0.05$ (ANOVA for columns; Student's $t$ tests for pairs of data across rows).

Table 3. Effects of Booroola genotype, treatment with cloprostenol and follicular diameter on concentration of inhibin

\begin{tabular}{llccc}
\hline & & \multicolumn{3}{c}{ Concentration of inhibin* } \\
\cline { 3 - 5 } $\begin{array}{l}\text { Booroola } \\
\text { genotype }\end{array}$ & Treatment & $\begin{array}{c}\text { Follicular diameter } \\
1-<2.5 \mathrm{~mm}\end{array}$ & $\begin{array}{c}\text { Follicular diameter } \\
\geq 2 \cdot 5-<5 \cdot 0 \mathrm{~mm}\end{array}$ & $\begin{array}{c}\text { Follicular diameter } \\
\geq 5 \cdot 0 \mathrm{~mm}\end{array}$ \\
\hline++ & Control & 251 & 263 & 283 \\
& & $(176,360)$ & $(120,583)$ & $(239,336)$ \\
& PG & 245 & 183 & 289 \\
BB & Control & $(118,390)$ & $(78,429)$ & $(195,422)$ \\
& PG & 242 & 248 & - \\
& & $(119,492)$ & $(173,356)$ & \\
& & $(1247,481)$ & $(184,608)$ & \\
\hline
\end{tabular}

${ }^{*}$ kiu $\mathrm{ml}^{-1}=$ all values are geometric means (and $95 \%$ confidence limits, $n=5$ sheep per treatment).

There are no significant differences across rows or columns.

highest content being found in the largest ++ follicles. There was no effect of treatment, genotype or follicular diameter on concentration of inhibin (Table 3). The overall geometric mean (and $95 \%$ confidence limits) concentration for inhibin across genotype, treatment and follicular diameter was $270(233,313) \mathrm{kiu} \mathrm{ml}^{-1}$. Irrespective of genotype and treatment, the inhibin concentration in oestrogenic follicles was significantly higher than in non-oestrogenic follicles ( $P<0.01$, Student's $t$ test); geometric mean concentrations (and $95 \%$ confidence limits) in the oestrogenic and non-oestrogenic follicles were $370(300,456)$ and $226(180,283) \mathrm{k} \mathrm{iu} \mathrm{ml}^{-1}$, respectively.

\section{Inhibin in ovarian tissues}

No gene-specific differences were noted in the inhibin content of theca interna, granulosa cells, corpora lutea or stroma (Table 4). The granulosa cells were the richest source of inhibin within the ovary, whereas the theca, stroma and corpora lutea contained very small amounts. 
K.P. McNatty et al.

Table 4. Inhibin concentrations in ovarian tissues

\begin{tabular}{lcc}
\hline Ovarian tissue* & Inhibin $\dagger$ & $\begin{array}{c}\text { Number of } \\
\text { sheep }\end{array}$ \\
\hline Stroma & $1 \cdot 1(1 \cdot 0,1 \cdot 3) \mathrm{iu} \mathrm{mg}^{-1}$ & 20 \\
Corpus luteum & $1 \cdot 8(1 \cdot 4,2 \cdot 3) \mathrm{iu} \mathrm{mg}^{-1}$ & 10 \\
$\quad$ (active) & $0 \cdot 3(0 \cdot 1,1 \cdot 0) \mathrm{iu} \mathrm{mg}^{-1}$ & 3 \\
$\quad$ (inactive) & $29(23,36)$ iu mg & \\
Theca interna & $403(286,570)$ iu per $10^{6}$ cells & 20 \\
Granulosa cells $\ddagger$ & 18 \\
\hline
\end{tabular}

*The theca interna, stroma and corpora lutea were each pooled separately for each sheep before extraction and assay.

†Values are geometric means (and $95 \%$ confidence limits).

$\ddagger$ Cells were recovered from a range of follicles of different diameters in individual sheep and the results for each animal averaged.

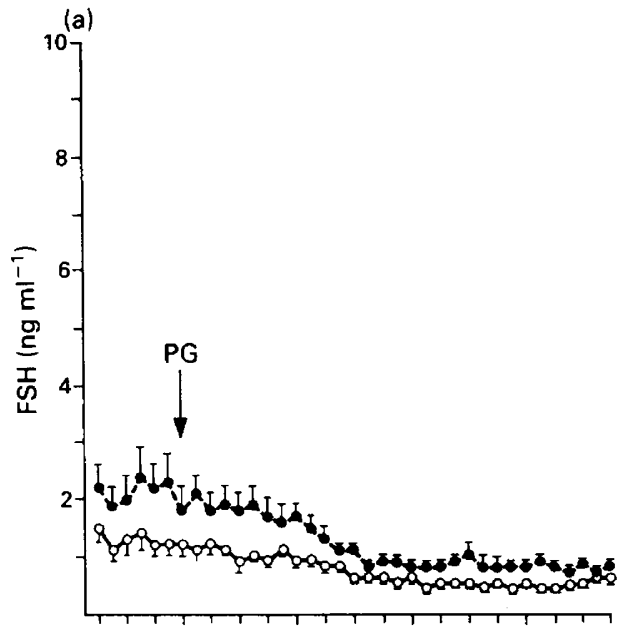

(c)

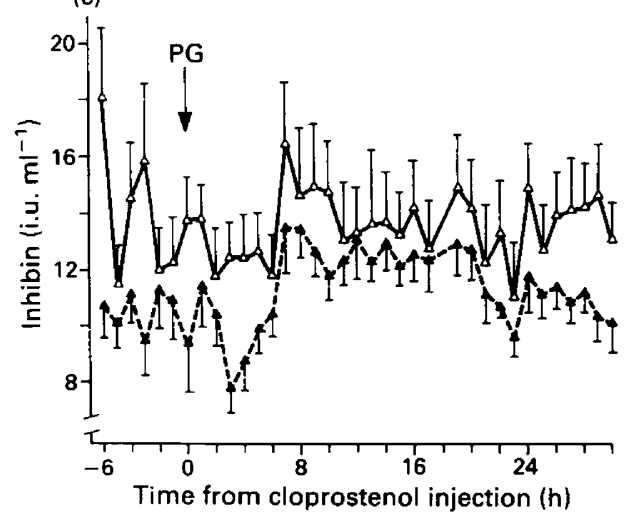

(b)

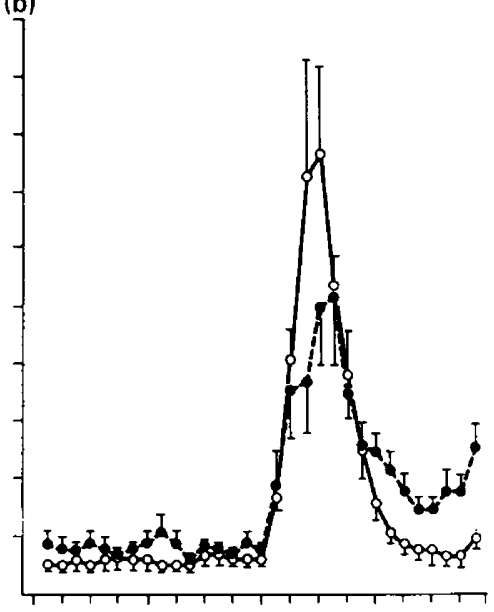

(d)

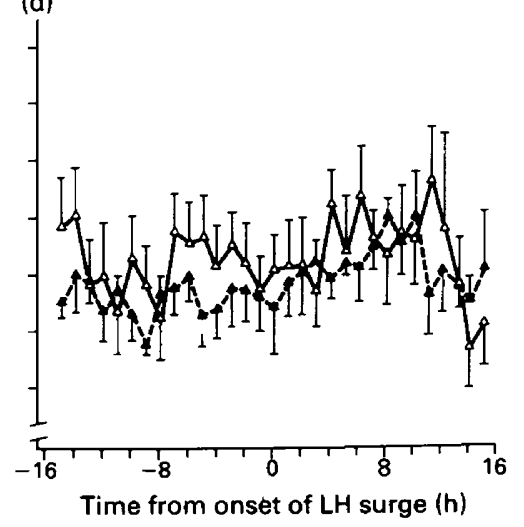

Fig. 2. Changes in the plasma concentrations of FSH (a) at about time of cloprostenol injection and (b) from onset of LH surge and changes in the concentration of inhibin (c) at about time of cloprostenol injection and (d) from onset of LH surge in BB (solid symbols) and ++ (open symbols) ewes. Values are means \pm SEM $(B B=$ nine ewes; $++=$ eight ewes $)$. 


\section{Changes in the plasma concentrations of FSH and inhibin around the onset of luteolysis and the preovulatory LH surge with respect to Booroola genotype}

The onset of luteolysis was defined as the time of cloprostenol injection, whereas the onset of the LH surge was the time one hour before the sustained rise in $\mathrm{LH}$ concentration to above $40 \mathrm{ng} \mathrm{ml}^{-1}$ (data not shown) (Fig. 2).

The mean \pm SEM ovulation rates in the BB genotype during the sampling period and during the subsequent cycle were $3.9 \pm 0.4$ and $4.0 \pm 0.6$, respectively, whereas for the ++ genotype the respective means were $1 \cdot 3 \pm 0.2$ and $1 \cdot 1 \pm 0 \cdot 1$. The mean \pm SEM body weights for the $B B$ and ++ genotypes were $45.4 \pm 0.9$ and $46.3 \pm 1.5 \mathrm{~kg}$, respectively. After cloprostenol injection, the mean \pm SEM times of onset to the preovulatory $\mathrm{LH}$ surge for the BB and ++ genotypes were $45 \pm 2$ and $45 \pm 3 \mathrm{~h}$, respectively.

From -6 to $0 \mathrm{~h}$ and from 0 to $30 \mathrm{~h}$, around luteolysis, the mean FSH but not inhibin concentrations were significantly higher in the BB compared with the ++ genotype (FSH: -6 to $0 \mathrm{~h}$; $P<0.05 ; 0$ to $30 \mathrm{~h}, P<0.02$; Student's $t$ test on one overall mean value per ewe). From -6 to $0 \mathrm{~h}$ the mean \pm SEM values in BB and ++ animals were $2 \cdot 1 \pm 0.3$ and $1 \cdot 3 \pm 0.2 \mathrm{ng} \mathrm{ml}^{-1}$ for FSH, respectively, and $10.5 \pm 0.9$ and $14.0 \pm 1.6 \mathrm{iu} \mathrm{ml}^{-1}$ for inhibin, respectively. From $0 \mathrm{~h}$ to $30 \mathrm{~h}$, the mean \pm SEM values in BB and ++ animals were $1.2 \pm 0.2$ and $0.7 \pm 0.1 \mathrm{ng} \mathrm{ml}^{-1}$ for FSH, respectively, and $11.5 \pm 0.7$ and $13.6 \pm 1.5 \mathrm{iu} \mathrm{ml}^{-1}$ for inhibin, respectively. For FSH, linear regression analysis of the values from 0 to $15 \mathrm{~h}$ revealed no significant difference in the rates of decline ( $\mathrm{BB}=-0.09 \pm 0.02 \mathrm{ng} \mathrm{ml}^{-1} \mathrm{~h}^{-1} ;++=-0.05 \pm 0.02 \mathrm{ng} \mathrm{ml}^{-1} \mathrm{~h}^{-1}$ ), but a significant difference in the intercepts $\left(\mathrm{BB}=2.2 \pm 0.3 \mathrm{ng} \mathrm{ml}^{-1} ;++=1.3 \pm 0.2 \mathrm{ng} \mathrm{ml}^{-1} ; P<0.02\right.$; KruskalWallis test). For inhibin the mean values from -6 to $0 \mathrm{~h}$ were not significantly different from those from 0 to $30 \mathrm{~h}$ after luteolysis. No significant correlations were noted between inhibin and FSH over any time period before or after luteolysis.

The FSH, but not inhibin, concentrations reached peak values at the same time as the LH surge. For FSH, the mean peak values in the BB and ++ genotypes were $6.7 \pm 1 \cdot 1$ and $8.7 \pm 1.9 \mathrm{ng} \mathrm{ml}^{-1}$; these values were not significantly different from one another. Moreover, the overall mean FSH concentrations from -15 to $0 \mathrm{~h}$ before the onset of the $\mathrm{LH}$ surge were not significantly different between the genotypes; the overall mean \pm SEM values were $0.8 \pm 0.1$ and $0.6 \pm 0.1 \mathrm{ng} \mathrm{m}^{-1}$ for the BB and ++ genotypes, respectively. The overall mean FSH concentrations from 8 to $15 \mathrm{~h}$ after the onset of the LH surge were significantly different $(P<0.01)$; the mean \pm SEM values were $2 \cdot 1 \pm 0.2$ and $1 \cdot 1 \pm 0.2 \mathrm{ng} \mathrm{ml}^{-1}$ for the BB and ++ genotypes, respectively. For inhibin, the mean \pm SEM values in the BB and ++ genotypes from -15 to $0 \mathrm{~h}$ before, or from 8 to $15 \mathrm{~h}$ after, the onset of the LH surge were not different from one another; the overall values from -15 to $+15 \mathrm{~h}$ around the $\mathrm{LH}$ surge were $11.6 \pm 0.6$ and $12.4 \pm 1.3 \mathrm{iu} \mathrm{ml}^{-1}$ for the BB and ++ genotypes, respectively; these values were not significantly different from one another. The coefficient of variability $(\mathrm{CV})$ for the hourly inhibin concentrations throughout the sampling period was similar for both genotypes; the combined CV was $22 \cdot 4 \pm 1.6$ (mean \pm SEM) $\%$.

Changes in the daily mean concentrations of FSH and inhibin in plasma throughout the oestrous cycle with respect to genotype

The mean \pm SEM ovulation rates before and after a cloprostenol-induced oestrous cycle in BB $(n=10)$ and ++ ewes $(n=10)$ were $5.9 \pm 0.3$ and $5 \cdot 3 \pm 0.3$, and $1 \cdot 3 \pm 0.2$ and $1.4 \pm 0.2$, respectively. The mean \pm SEM bodyweights during the study were $49.5 \pm 1.9$ and $50.5 \pm 2.8 \mathrm{~kg}$, for the BB and ++ animals, respectively. On 26 out of 28 sampling days, the mean FSH values in BB animals were higher than those in ++ animals (Fig. 3). The overall mean \pm SEM values in BB and ++ were $1.9 \pm 0.1$ and $1.2 \pm 0.1 \mathrm{ng} \mathrm{ml}^{-1}$, respectively; these values were significantly different $(P<0.001$; Student's $t$ test). In contrast, the overall mean \pm SEM concentrations of progesterone in BB and ++ ewes were $0.9 \pm 0.1$ and $0.8 \pm 0.1 \mathrm{ng} \mathrm{ml}^{-1}$, respectively, with these values not being 

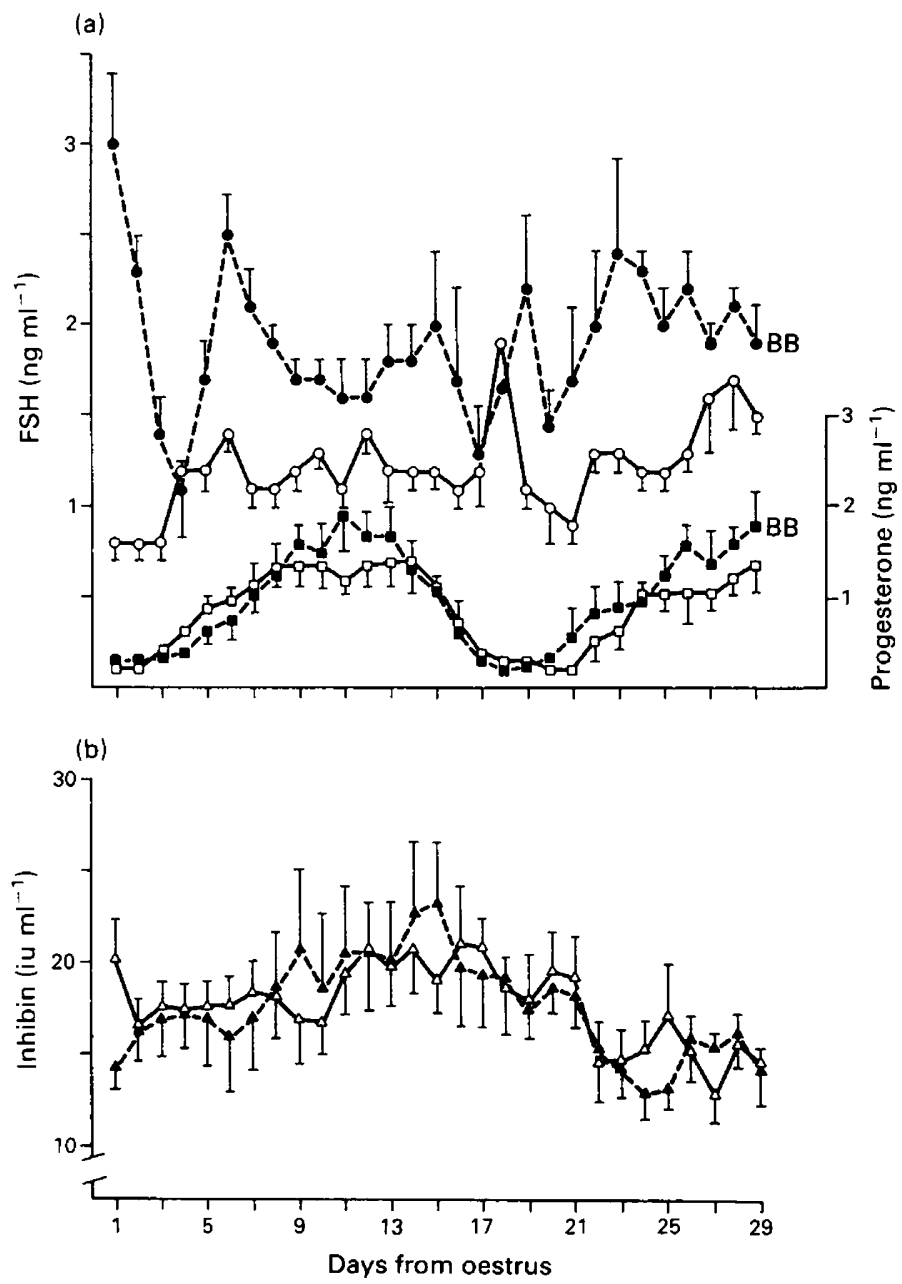

Fig. 3. Mean $( \pm$ SEM) daily changes in the plasma concentrations of (a) FSH $(\bullet \bullet, B B ;-\infty$,

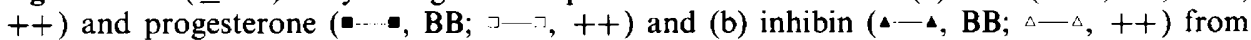
the onset of a cloprostenol-induced oestrus in ten animals per genotype.

different from one another. Likewise, the overall mean \pm SEM values for inhibin in the BB and ++ genotypes were not different: $17.5 \pm 1.7$ and $18.1 \pm 1.7 \mathrm{iu} \mathrm{ml}^{-1}$, respectively. The coefficient of variability for the daily inhibin values for both genotypes were similar; the combined mean $\mathrm{CV}$ was $22 \cdot 4 \pm 1 \cdot 6(\mathrm{SEM}) \%$.

\section{Changes in the mean plasma concentrations of FSH and inhibin during the luteal phase with respect to Booroola genotype}

The mean \pm SEM bodyweights for the BB and ++ animals were $48.7 \pm 1.7$ and $49.8 \pm 1.4 \mathrm{~kg}$, respectively. The mean \pm SEM plasma concentrations of FSH and inhibin in the $26 \mathrm{BB}$ and $24++$ Booroola ewes were $1.4 \pm 0.08 \mathrm{ng} \mathrm{ml}^{-1}(\mathrm{FSH})$ and $19.0 \pm 1.0 \mathrm{iu} \mathrm{ml}^{-1}$ (inhibin) and $0.9 \pm 0.06 \mathrm{ng}$ $\mathrm{ml}^{-1}(\mathrm{FSH})$ and $16.9 \pm 1.6 \mathrm{iu} \mathrm{ml}^{-1}$, respectively; the FSH but not inhibin concentrations were significantly different with respect to genotype $(P<0.001 ; t$ test $)$. No significant linear relationship was noted between FSH and inhibin for either the combined data for both genotypes or for each genotype separately. 
Sequential inhibin but not FSH concentrations over the three sampling days were often significantly correlated for both genotypes $(P<0.05)$. The inhibin correlations for sample 1 compared with sample 2, sample 2 compared with sample 3 and sample 1 compared with sample 3 for the $\mathrm{BB} /++$ genotypes were $0.36(P<0.08) / 0.48(P<0.03), 0.86(P<0.001) / 0.83(P<0.001)$ and $0.53(P<0.01) / 0.30(P<0.2)$, respectively.

\section{Discussion}

The present results on Booroola ewes show (i) that the mean ovarian venous concentration of inhibin is about four times higher than in peripheral plasma; (ii) the mean ovarian secretion rate of inhibin is four times higher from oestrogen-active ovaries compared with oestrogen-inactive ovaries and (iii) that the mean follicular fluid concentration of inhibin is about 1.6 times higher in oestrogen-active compared with oestrogen-inactive ovaries. Moreover, these studies show that ovariectomy causes a significant reduction in plasma inhibin concentrations and that the concentrations at $6 \mathrm{~h}$ after ovariectomy remain unchanged thereafter. Collectively, these results are consistent with previous studies using either the same immunoassay procedures (Robertson et al., 1988; Findlay et al., 1990) or bioassay (Henderson et al., 1984). The results also confirm that the ovary is a major source of inhibin. However, the finding that about $50 \%$ of the animals continued to have persistent, albeit low, concentrations of inhibin after ovariectomy was unexpected. In two animals, inhibin immunoreactivity was present in all samples at concentrations that were approximately $70 \%$ of those before ovariectomy; the extra-ovarian sources of inhibin were not identified. No gene-specific differences were noted with respect to which animals contained measurable inhibin concentrations after ovariectomy.

The inhibin antibody used in this study (No. 1989) crossreacts with a pro- $\alpha \mathrm{C}$ form of inhibin and may also recognize the native $\alpha$ subunit as well as native inhibin (Findlay et al., 1990; Robertson, 1990; Schneyer et al., 1990). The extent to which subunits are present in the follicular fluid, ovarian tissues and ovarian venous or peripheral blood of the ewe is at present unknown. Knight et al. (1989) report the presence of a $25-26 \mathrm{kDa}$ form of the inhibin $\alpha$ subunit monomer in bovine follicular fluid and ovarian venous plasma but could not identify this form in ovarian venous plasma of ewes. Robertson et al. (1989) and Sugino et al. (1989) have reported the isolation of a pro- $\alpha \mathrm{C}$ in bovine follicular fluid and this material was estimated to represent $>10-20 \%$ of the total inhibin immunoreactivity in follicular fluid. The extent and origins of these potential crossreacting forms that might exist in the plasma of ovariectomized ewes may vary. The selection of ovariectomized plasmas for use in radioimmunoassay therefore needs to be screened carefully and the same pool needs to be used in all assays as in the present report. Failure to satisfy those criteria may give misleading results. Statements of previous reports suggesting that more information is required on inhibin subunits and isoforms, in plasma, follicular fluid and tissues together with their bioactivities and relative levels of expression in gonadal and extra-gonadal tissues can only be emphasized (Leversha et al., 1987; Robertson, 1990). Despite the above uncertainties about inhibin subunits, all the biological fluids studied in the present report contained inhibin immunoreactivity with parallel activity to the WHO and OFF2 reference standards.

In four separate experiments we were unable to show any gene-specific differences in the plasma concentrations of immunoreactive inhibin even though the FSH concentrations were always significantly higher in BB compared with ++ ewes. No gene-specific differences were noted for the ovarian secretion rates of inhibin or in the follicular fluid or ovarian tissue concentrations. Collectively, these findings together with those of Henderson et al. (1991) and Fleming et al. (1990b) do not support the notion that inhibin is linked to the $\mathrm{Fec}^{\mathrm{B}}$ gene or is responsible for the gene-specific differences in plasma FSH concentrations. Moreover, these findings suggest that the differences in mean immunoreactive inhibin in BB/B + ewes compared with control Merinos reported by McNatty et al. (1991b) is probably due to use of inappropriate control animals rather than an effect of the $B$ gene. 
The present results are, in part, at variance with those of Tsonis et al. (1988) who, although reporting no gene differences in inhibin secretion during the luteal phase, noted a significant difference at $48 \mathrm{~h}$ but not at 24 or $36 \mathrm{~h}$ after cloprostenol injection with a higher secretion rate in $\mathrm{B}+/ \mathrm{BB}$ animals than in ++ animals. In our study no gene-specific differences in plasma inhibin were noted at any time during the follicular or luteal phase. In part, the discrepancy may be explained by the fact that, in the study by Tsonis et al. (1988), only four B + or BB animals and six ++ animals were examined and that these animals experienced their pre-ovulatory LH surges at markedly different times after cloprostenol injection (i.e. $48 \mathrm{~h}$ to $>72 \mathrm{~h}$ ).

The results of this study are consistent with those of Cummins et al. (1983), who showed that ++ ewes have a higher ovarian content of inhibin than do BB ewes. In this study, the follicle numbers were not different between the genotypes. The only difference was that ++ but not BB ewes had follicles $\geq 5.0 \mathrm{~mm}$ diameter and that the inhibin contents but not concentrations were about fivefold higher in these follicles relative to those $<5.0 \mathrm{~mm}$ diameter. Thus, in the present study, one would expect higher overall inhibin contents in ++ relative to BB ewes.

In examining the intra-ovarian compartments for inhibin in Booroola ewes (Table 4), it is clear that the richest sites are follicular fluid and granulosa cells; this can be inferred from the fact that the approximately 21 follicles $\geq 1 \mathrm{~mm}$ diameter in each ewe have a total of about $12-35 \times 10^{6}$ granulosa cells (i.e. $0 \cdot 96-2 \cdot 80 \mathrm{mg}$ protein), whereas the theca interna, stroma and luteal tissue each total $\leqslant 20 \mathrm{mg}$ (i.e. $\leqslant 1.2 \mathrm{mg}$ protein), $\leqslant 500 \mathrm{mg}$ and $\leqslant 1000 \mathrm{mg}$ wet weight respectively (Peters $\&$ McNatty, 1980). These data suggest that Booroola ewes do not differ from other breeds/strains with respect to their intra-ovarian sources of inhibin (Mann et al., 1989; Rodgers et al., 1989).

The present findings in Booroola ewes that show no overall change in inhibin secretion rate between the luteal phase and a cloprostenol-induced follicular phase and no obvious changes in peripheral plasma during the luteal or follicular phases are consistent with the results of McNeilly \& Baird (1989) and Mann et al. (1989) who used an inhibin $\alpha$ subunit assay, but our results differ from those of Findlay et al. (1990) who used a similar assay to that described in the present study. In the last report, it was concluded that the inhibin concentrations increased during the follicular phase concomitant with the development of the dominant follicle. In the present study, the oestrogen secretion rate increased during the follicular phase concomitant with a marked reduction in progesterone secretion. Moreover as mentioned earlier ovaries with oestrogenic follicles secreted significantly more inhibin than non-oestrogenic ovaries. Perhaps the presence or absence of an increase in inhibin secretion during the follicular phase is related to the proportions (or numbers) of non-oestrogenic and oestrogenic follicles present on the ovaries at this phase of the cycle. All follicles $\geq 1 \mathrm{~mm}$ diameter have a potential to secrete inhibin (Table 2) but not oestradiol. Thus, the presence of a large number of non-oestrogenic follicles may sometimes mask the contribution of inhibin but not oestradiol secretion from the preovulatory follicle during the follicular phase.

Significant correlations within sheep for inhibin concentrations taken every second or third day during the luteal phase were observed. Findlay et al. (1990) reported that the mean CV from hourly sampling during the luteal phase was about $17 \%$. In this study the mean CVs from hourly or daily samplings were about $22 \%$ for both genotypes. The degree of constancy for plasma inhibin supports the notion that a number of asynchronously developing follicles contribute inhibin to the circulating plasma. Alternatively, it is possible that the degree of constancy can be attributed in part to the presence of crossreacting materials of extra-ovarian origin. Moreover, the failure to establish any significant correlation between FSH and inhibin from hourly sampling after a cloprostenol-induced follicular phase (Expt 1), from daily sampling through the oestrous cycle (Expt 3) and from blood sampling once every second or third day across the luteal phase (Expt 4) is consistent with the notion that at least some temporal fluctuations in plasma FSH are not regulated by inhibin, even though inhibin contributes substantially to the overall negative feedback control of FSH (Mann et al., 1989; Campbell et al., 1990). In some, but not all, circumstances positive correlations have been shown between FSH and inhibin (Findlay et al., 1990) consistent with the notion that FSH at certain concentrations will stimulate inhibin synthesis in vivo (Lee et al., 1982; 
Buckler et al., 1988; K. P. McNatty et al., unpublished observations) and in vitro (Henderson et al., 1984; Zhiwen et al., 1987).

In summary, these studies suggest that the patterns of inhibin secretion and the intra-ovarian origins of inhibin in highly fecund Booroola sheep are similar to those of other sheep breeds or strains. Moreover, we conclude that there are no differences in immunoreactive inhibin concentrations in peripheral or ovarian venous plasma or in follicular fluid or intra-ovarian tissues between animals that were homozygous carriers or non-carriers of the $B$ gene. Thus we suggest that inhibin is not associated with the $\mathrm{Fec}^{\mathbf{B}}$ gene.

We thank our colleagues at the Invermay Agricultural Research Centre for their help in this study and in particular George Davis and Kaye Isaacs for supplying the animals as well as details of their reproductive records; Louise Shaw, Stan Lun and Peter Smith for help with animal surgery, animal care and blood sampling; Seow-Ling Seah for statistical advice; Sue Dolden for typing the manuscript; The National Hormone and Pituitary Program (University of Maryland School of Medicine) and the National Institute of Diabetes and Digestive and Kidney Diseases for the ovine FSH RIA kit and the ovine LH standards; and the National Institute of Biological Standards and Control, Potters Bar, Hertfordshire, for the WHO porcine inhibin standard.

\section{References}

Bindon, B.M. (1984) Reproductive biology of the Booroola Merino sheep. Australian Journal of Biological Science 37, 163-189.

Buckler, H.M., Healy, D.L. \& Burger, H.G. (1988) Purified FSH stimulates production of inhibin by the human ovary. Journal of Endocrinology 122, 279-285.

Campbell, B.K., Mann, G.E., McNeilly, A.S. \& Baird, D.T. (1990) The pattern of ovarian inhibin, estradiol, and androstenedione secretion during the estrous cycle of the ewe. Endocrinology 127, 227-235.

Cummins, L.J., O'Shea, T., Bindon, B.M., Lee, V.W.K. \& Findlay, J.K. (1983) Ovarian inhibin content and sensitivity to inhibin in Booroola and control strain Merino ewes. Journal of Reproduction and Fertility $67,1-7$.

Davis, G.H., Montgomery, G.W., Allison, A.J., Kelly, R.W. \& Bray, A.R. (1982) Segregation of a major gene influencing fecundity in progeny of Booroola sheep in New Zealand. New Zealand Journal of Agricultural Research 25, 525-529.

Findlay, J.K., Clarke, I.J. \& Robertson, D.M. (1990) Inhibin concentrations in ovarian and jugular venous plasma and the relationship of inhibin with follicle stimulating hormone and luteinizing during the ovine estrous cycle. Endocrinology 126, 528-535.

Fleming, J.S., Lun, S., Smith, P.\& McNatty, K.P. (1990a) Pituitary receptors for gonadotrophin-releasing hormone in Booroola Merino ewes which were noncarriers or homozygotes of the fecundity gene $F$. Journal of Neuroendocrinology 2, 601-604.

Fleming, J.S., Greenwood, P.J. \& McNatty, K.P. (1990b) Messenger RNA transcripts for FSH $\beta, L H \beta, \alpha$ inhibin and $\beta_{A}$ inhibin in Booroola sheep with and without the fecundity gene F. Proceedings of the Australian Society of Reproductive Biology Abstract 130.

Fry, R.C., Cahill, L.P., Cummins, J.T., Bindon, B.M., Piper, L.R. \& Clarke, I.J. (1987) The half-life of follicle stimulating hormone in ovary-intact and ovariectomized Booroola and control Merino ewes. Journal of Reproduction and Fertility 81, 611-615.

Henderson, K.M., Franchimont, P., Charlet-Renard, Ch. \& McNatty, K.P. (1984) Effect of follicular atresia on inhibin production by bovine granulosa cells in vitro and inhibin concentrations in follicular fluid. Journal of Reproduction and Fertility 72, 1-8.

Henderson, K.M., McNatty, K.P., Wards, R.L., Heath, D.A. \& Lun, S. (1991) Inhibin production in vitro by granulosa cells from Booroola ewes which were either homozygous or non-carriers of a fecundity gene influencing their ovulation rate. Journal of Reproduction and Fertility 92, 147-157.

Knight, P.G., Beard, A.J., Wrathall, J.H.M. \& Castillo, R.J. (1989) Evidence that the bovine ovary secretes large amounts of monomeric inhibin $\alpha$ subunit and its isolation from bovine follicular fluid. Journal of Molecular Endocrinology 2, 189-200.

Lee, V.W.K., McMaster, J., Quigg, H. \& Leversha, L. (1982) Ovarian and circulating inhibin levels in immature female rats treated with gonadotrophin and after castration. Endocrinology 111, 1849-1854.

Leversha, L.J., Robertson, D.M., de Vos, F.L., Morgan, F.J., Hearn, M.T.W., Wettenhall, R.E.H., Findlay, J.K., Burger, H.G. \& de Krester, D.M. (1987) Isolation of inhibin from ovine follicular fluid. Journal of Endocrinology 113, 213-221.

McLachlan, R.I., Robertson, D.M., Burger, H.G. \& de Krester, D.M. (1986) The radioimmunoassay of bovine and human follicular fluid and serum inhibin. Molecular and Cellular Endocrinology 46, 175-185.

McNatty, K.P., Dobson, C., Gibb, M., Kieboom, L. \& Thurley, D.C. (1981) Accumulation of luteinizing hormone, oestradiol and androstenedione by sheep ovarian follicles in vivo. Journal of Endocrinology 91, 99-109.

McNatty, K.P., Lun, S., Heath, D.A., Ball, K., Smith, P., Hudson, N.L., McDiarmid, J., Gibb, M. \& Henderson, K.M. (1986) Differences in ovarian activity between 
Booroola $\times$ Merino ewes which were homozygous, heterozygous and non-carriers of a major gene influencing their ovulation rate. Journal of Reproduction and Fertility 77, 193-205.

McNatty, K.P., Hudson, N., Henderson, K.M., Gibb, M., Morrison, L., Ball, K. \& Smith, P. (1987) Differences in gonadotrophin concentrations and pituitary responsiveness to $\mathrm{GnRH}$ between Booroola ewes which were homozygous $(\mathrm{FF}$, heterozygous $(\mathrm{F}+)$ and non-carriers $(++)$ of a major gene influencing their ovulation rate. Journal of Reproduction and Fertility 80, 577-588.

MeNatty, K.P., Fisher, M., Collins, F., Hudson, N.L., Heath, D.A., Ball, K. \& Henderson, K.M. (1989a) Differences in the plasma concentrations of FSH and LH in ovariectomized Booroola FF and ++ ewes. Journal of Reproduction and Fertility 85, 705-713.

McNatty, K.P., Hudson, N.L., Collins, F., Fisher, M., Heath, D.A. \& Henderson, K.M. (1989b) Effects of oestradiol-17 $\beta$, progesterone or bovine follicular fluid on the plasma concentrations of FSH and LH in ovariectomized Booroola ewes which were homozygous carriers or non-carriers of a fecundity gene. Journal of Reproduction and Fertility 87, 573-585.

MeNatty, K.P., Hudson, N.L., Shaw, L., Condell,L.A., Ball, K., Seah, S-L. \& Clarke, I.J. (1991a) GnRHinduced gonadotrophin secretion in ovariectomized Booroola ewes with hypothalamic-pituitary disconnection. Journal of Reproduction and Fertility 91, 583-592.

McNatty, K.P., Henderson, K.M., Fleming, J.S., Clarke, I.J., Bindon, B.M., O'Shea, J., Hillard, M.A. \& Findlay, J.K. (1991b) The physiology of the Booroola ewe. In Major Genes for Reproduction in Sheep, pp. 105-124. Eds J. M. Elsen, L. Bodin \& J. Thimonier. INRA, Paris.

McNeilly, A.S. \& Baird, D.T. (1989) Episodic secretion of inhibin into the ovarian vein during the follicular phase of the oestrous cycle in the ewe. Journal of Endocrinology 122, 287-292.

Mann, G.E., McNeilly, A.S. \& Baird, D.T. (1989) Source of ovarian inhibin secretion during the oestrous cycle of the sheep. Journal of Endocrinology 123, 181-188.

Montgomery, G.W., Sise, J.A., Greenwood, P.J. \& Fleming, J.S. (1990) The Booroola F gene mutation in sheep is not located close to the FSH- $\beta$ gene. Journal of Molecular Endocrinology 5, 167-173.

Peters, H. \& McNatty K.P. (1980) Ovarian hormones. In The Ovary, pp. 43-45. Eds H. Peters \& K. P. MeNatty. Granada Publishing, London.

Piper, L.R. \& Bindon, B.M. (1991) The Booroola gene $\mathrm{Fec}^{\mathbf{B}}$ in Australia. In Major Genes for Reproduction in Sheep, pp. 43-45. Eds J. M. Elsen, L. Bodin \& J. Thimonier, INRA, Paris.
Piper, L.R., Bindon, B.M. \& Davis, G.H. (1985) The single gene inheritance of the high litter size of the Booroola Merino. In Genetics of Reproduction in Sheep, pp. 115-125. Eds R. B. Land \& D. W. Robinson, Butterworths, London.

Robertson, D.M. (1990) The measurement of inhibin. Reproduction Fertility and Development 2, 101-106.

Robertson, D.M., Ellis, S., Foulds, L.M., Findlay, J.K. \& Bindon, B.M. (1984) Pituitary gonadotrophins in Booroola and control Merino sheep. Journal of Reproduction and Fertility 71, 189-197.

Robertson, D.M., Hayward, S., Irby, D., Jacobsen, J., Clarke, L., McLachlan, R.I. \& de Kretser, D.M. (1988) Radioimmunoassay of rat serum inhibin: changes after PMSG stimulation and gonadectomy. Molecular and Cellular Endocrinology 58, 1-8.

Robertson, D.M., Giacometti, M., Foulds, L.M., Lahnstein, J., Goss, N.H., Hearn, M.T.W. \& de Kretser, D.M. (1989) Isolation of inhibin $\alpha$-subunit precursor proteins from bovine follicular fluid. Endocrinology 125, 2141-2149.

Rodgers, R.J., Stuchbery, S.J. \& Findlay, J.K. (1989) Inhibin mRNAs in ovine and bovine follicles and corpora lutea throughout the estrous cycle and gestation. Molecular and Cellular Endocrinology 62, 95-101.

Schneyer, A.L., Mason, A.J., Burton, L.E., Ziegner, J.R. \& Crowley, W.F., Jr (1990) Immunoreactive inhibin a-subunit in human serum: implications for radioimmunoassay. Journal of Clinical Endocrinology and Metabolism 70, 1208-1212.

Sugino, K., Nakamura, T., Takio, N., Titami, K., Miyamoto, K., Hasegawa, Y., Igarashi, M. \& Sugino, H. (1989) Inhibin $\alpha$-subunit monomer is present in follicular fluid. Biochemical Biophysical Research Communications 159, 1323-1329.

Tsonis, C.G., Baird, D.T., Campbell, B.K., Downing, J.A. \& Scaramuzzi, R.J. (1988) Secretion of bioactive inhibin by the ovary of the Booroola Merino ewe with or without a copy of the fecundity (F) gene. Journal of Endocrinology 119, R5-R8.

Webb, R., Baxter, G., McBride, D., Nordblom, G.D. \& Shaw, M.P.K. (1985) The measurement of testosterone and oestradiol-17 $\beta$ using iodinated tracers and incorporating an affinity chromatography extraction procedure. Journal of Steroid Biochemistry 23, 1043-1051.

Zhiwen, Z., Carson, R.S., Herrington, A.C., Lee, V.W.K. \& Burger, H.G. (1987) FSH and somatomedin C stimulate inhibin production by rat granulosa cells in vitro. Endocrinology 120, 1633-1638.

Received 3 April 1991 